\title{
Simulating the Gene Flow of Genetically Modified Maize in Taiwan
}

\author{
Bo-Jein Kuo1, Shuo-Cheng Nieh1, Guang-Jauh Shieh², Wen-Shin Lin ${ }^{3 *}$ \\ ${ }^{1}$ Department of Agronomy, National Chung Hsing University, Taichung, Taiwan \\ ${ }^{2}$ Crop Science Division, Taiwan Agricultural Research Institute, Council of Agriculture, Executive Yuan, Taichung, \\ Taiwan \\ ${ }^{3}$ Department of Plant Industry, National Pingtung University of Science and Technology, Pingtung, Taiwan \\ Email: ${ }^{*}$ wslin@mail.npust.edu.tw
}

Received 17 February 2014; revised 22 March 2014; accepted 5 April 2014

Copyright (C) 2014 by authors and Scientific Research Publishing Inc.

This work is licensed under the Creative Commons Attribution International License (CC BY).

http://creativecommons.org/licenses/by/4.0/

(c) (i) Open Access

\section{Abstract}

A field experiment was conducted in Taiwan to measure the cross-pollination (CP) rate of maize pollen recipients from pollen sources using phenotypic marker and to determine the isolation distance between the 2 maize varieties. A waxy variety (Black Pearl) with purple kernels simulated the genetically modified (GM) pollen donor, and another waxy variety (White Pearl) with white kernels simulated the non-GM recipient. For the first crop, the total area was approximately 1.5 ha with a pollen source and recipient acreage ratio of approximately 1:32. For the second crop, the total area was approximately 1.83 ha with a ratio of approximately $1: 17.3$. The source fields were surrounded by the recipient fields for 2 crop seasons. The results showed that the rate of CP was $<0.05 \%$ beyond $15 \mathrm{~m}$ upwind and $84.8 \mathrm{~m}$ downwind in all crop seasons. The CP rate was below $5 \%$ at a distance of $10 \mathrm{~m}$ in the downwind direction. A sample with $0.24 \% \mathrm{CP}$ was recorded at $107.3 \mathrm{~m}$ downwind; however, the $\mathrm{CP}$ rate was $0 \%$ at $68 \mathrm{~m}$ upwind. Three empirical models were used, that is, exponential, $\log / \log$ and $\log / \log$, and a simplified Gaussian Plume model, to examine the relationship between the CP rates and the source-field distances. All of the models were appropriate for predicting CP rates, and the Gaussian Plume model performed better compared to the empirical models. The results show that it is possible to control CP from foreign pollen by using an appropriate isolation distance.

\section{Keywords}

Cross-Pollination, Gaussian Plume Model, Gene Flow Model, Maize, Xenia Effect

\section{Introduction}

In 2012, the global acreage of commercial planting of genetically modified (GM) crops reached 170 million

\footnotetext{
${ }^{*}$ Corresponding author.
} 
hectares. The principal GM crops are soybeans, maize, cotton, and canola. Worldwide acreage of GM maize is over 50 million hectares [1]. Maize (Zea mays L) is a monoecious, diclinous, protandrous, and wind-pollinated plant with abundant pollen. Because of the anemophilous characteristic of maize, the principal source of adventitious mixing between GM and non-GM maize is the gene flow between neighboring fields [2]-[4]. In the European Union (EU), all countries are asked to develop national coexistence measures to ensure that GM crops are below the legal threshold value of $0.9 \%$ for labeling GM maize food and feed [5].

To reduce the adventitious presence from source pollen to recipient fields, extensive research has been conducted on maize gene flow [2] [6]-[11]. Most of studies measured the levels of cross-pollination in the recipient field at various distances from the pollen source by detecting the xenia effect on the progeny. Hence, the cross-pollination rate of maize recipients is defined as the percentage of off-types in the progeny. Based on scientific results published on maize gene flow and cross-pollination, a range of isolation distances between 10 and $50 \mathrm{~m}$ are recommended to maintain the cross-pollination rate below the tolerance threshold of $0.9 \%$. However, an isolation distance of $50 \mathrm{~m}$ is necessary for recipient fields smaller than 1 ha and fields of low depth, especially when in the downwind direction [5].

In the past 2 decades, research on biotechnology has been supported to develop GM organisms in Taiwan. Currently, none of GM crops are produced in Taiwan. All GM foods in the domestic market rely on foreign imports, particularly maize and soybeans. In 2010, the United States exported more than US\$613 million of maize and US\$653 million of soybeans to Taiwan. Taiwan is the fifth largest export market for US maize and soybeans. Approximately half of the total US agricultural, fish, and forest products exported to Taiwan are biotechnology products [12]. In Taiwan, food products composed of GM soybeans and corn containing more than 5\% transgenic material by weight of the finished product must be labeled with the words "Genetically Modified” (GM) or "Containing Genetically Modified” soybeans and corn, respectively. Currently, the total acreage of maize is approximately 18,000 ha, in which approximately two-thirds are planted with forage corn and the rest with grain corn. Recently, to increase food security and promote the use of fallow, increasing maize cultivation has been encouraged.

To date no study has been conducted on maize gene flow and cross-pollination on a field-scale level in Taiwan. Most agricultural fields in Taiwan are fragmented landscapes and spatially heterogeneous with minimal pollen sources and recipients.

The purposes of this study are to detect the cross-pollination (CP) rates of maize at various distances from source plots to recipient fields and to construct a gene flow model. This information is useful for management strategies of GM crops and provides a basis for discussion on the issues of coexistence between GM and non-GM crops in Taiwan.

\section{Materials and Methods}

\subsection{Field Design}

The field experiment was conducted in 2009 at the experimental fields of the Taiwan Agriculture Research Institute (TARI), Wufeng, located at $24^{\circ} 1^{\prime} \mathrm{N}, 120^{\circ} 41^{\prime} \mathrm{E}$. The soil was a silty-clay loam. The total area of the first crop was approximately 1.5 ha with a pollen source and recipient acreage ratio of approximately 1:32. The pollen source (50 by $9 \mathrm{~m}$ ) was facing south (Figure 1(a)). Because of irrigation concerns, the experimental fields at TARI were composed of plots with an area of 0.5 ha each. The experimental fields consisted of 3 side-by-side plots (Nos.76, 78, and 80) separated by 2 field roads, 5.25 and $6 \mathrm{~m}$ wide, respectively. The total area of the second crop was approximately 1.83 ha with a ratio of approximately 1:17.3. The source plot (50 by $20 \mathrm{~m}$ ) was located in a northward direction (Figure 1(b)). The experimental fields included 4 plots (Nos. 76, 78, 80, and a portion of No. 82) separated by 3 field roads (4.1, 7.95, and $6.05 \mathrm{~m}$ wide, respectively). The source fields for the 2 crop seasons were surrounded by the recipient fields.

\subsection{Plant Materials and Planting Dates}

Table 1 shows the agronomic characteristics of plant materials. The Black Pearl, used as the pollen donor, had purple kernels. The White Pearl, with white kernels, was used as the recipient. Both the Black Pearl and White Pearl are commercial waxy maize varieties produced from Known-You Seed Co. Both had periods from planting-to-flowering of approximately 40 - $50 \mathrm{~d}$. We investigated the kernel pericarp color of the maize, which 


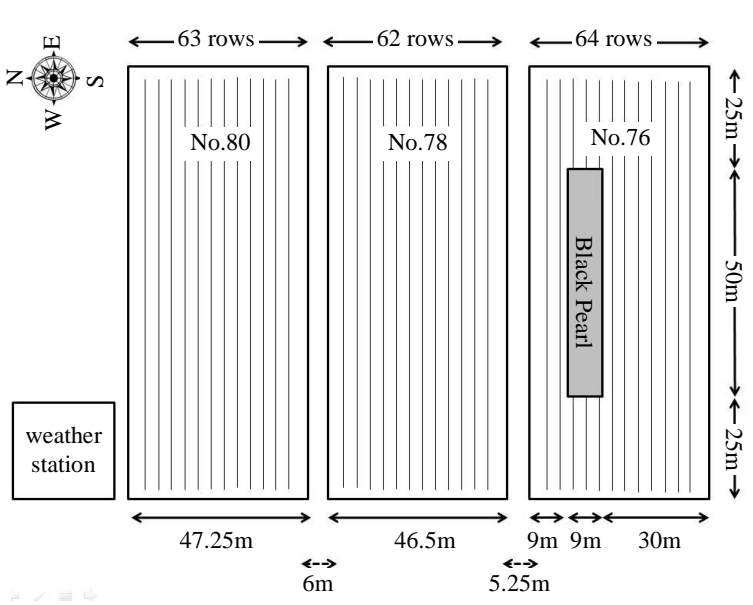

(a)

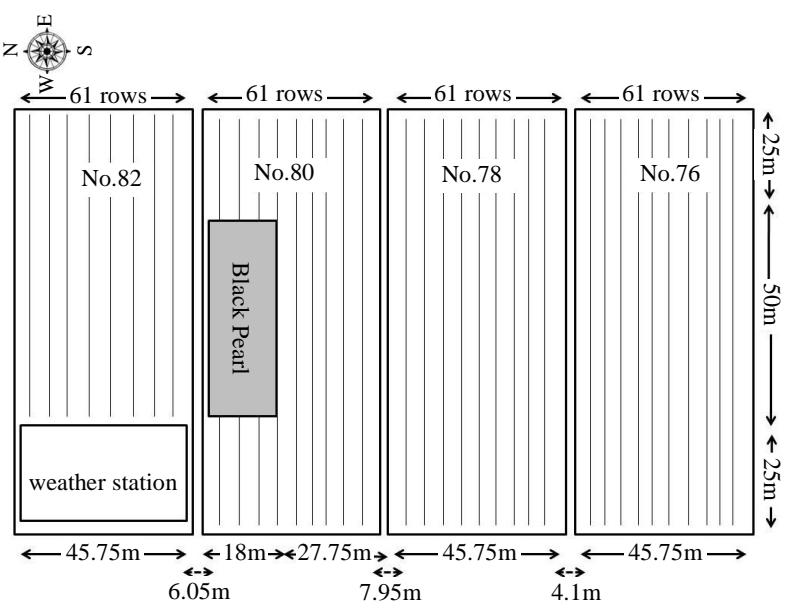

(b)

Figure 1. Field design of the experiments in 2009. (a) The first crop season; (b) The second crop season. The gray area is for pollen source and the remainder area is for recipient.

Table 1. Planting material, dimensions, sowing date, tasseling date and silking date.

\begin{tabular}{|c|c|c|c|c|c|c|}
\hline \multirow{2}{*}{$\begin{array}{l}\text { Crop } \\
\text { season }\end{array}$} & \multirow{2}{*}{ Dimensions } & \multirow{2}{*}{$\begin{array}{l}\text { Size of } \\
\text { source plot }\end{array}$} & \multirow{2}{*}{ Hybrid name } & \multicolumn{3}{|c|}{ Date } \\
\hline & & & & Planting & $50 \%$ pollen shed & $50 \%$ silking \\
\hline $1^{\text {st }}$ & $150 \times 100$ & $10 \times 50$ & $\begin{array}{l}\text { White Pearl (white) (Pollen recipient) } \\
\text { Black Pearl (purple) (Pollen source) }\end{array}$ & $\begin{array}{l}19 \text { Feb. } \\
19 \text { Feb. } \\
23 \text { Feb. }\end{array}$ & $\begin{array}{l}17 \text { Apr. } \\
22 \text { Apr. }\end{array}$ & 19 Apr. \\
\hline $2^{\text {nd }}$ & $200 \times 100$ & $20 \times 50$ & $\begin{array}{l}\text { White Pearl (white) (Pollen recipient) } \\
\text { Black Pearl (purple) (Pollen source) }\end{array}$ & $\begin{array}{l}8 \text { Sep. } \\
8 \text { Sep. }\end{array}$ & $\begin{array}{l}23 \text { Oct. } \\
26 \text { Oct. }\end{array}$ & 25 Oct. \\
\hline
\end{tabular}

results from the xenia effect. The xenia effect is caused by the endosperm maize type with different pollen sources.

The experiment used conventional farming practice methods. The distance between individual plants in each row was $0.3 \mathrm{~m}$, and the distance between rows was $0.75 \mathrm{~m}$. The density was 44,400 plants per ha.

To ensure that the silking period of the White Pearl (pollen recipient) and the flowering period of the Black Pearl (pollen source) overlapped, the Black Pearl was divided into 2 batches according to planting time. For the first crop season, the recipient and first batch of Black Pearl were planted on 19 February, and the second batch was planted on 23 February. Because the results of the first crop season showed a close synchrony between pollen shedding from the source plants and silking of the recipient, in the second crop season both pollen donors and recipients were planted on 8 September.

\subsection{Climate Monitoring during the Flowing Period}

The meteorological information, including wind speed and direction, was recorded by the weather station located at the corner of the experiment field. For $7 \mathrm{~d}$ before and after the silking period, the wind speed and direction were recorded from 6:00 a.m. to 4:00 p.m. with hours being used as the unit of measure. Changes in wind speed and wind roses were used to interpret the trends in the wind speed and direction.

\subsection{Data Collection and Calculation of CP Rate}

In the first crop, the ears of the recipients were sampled from rows on the south and north sides of the pollen source as follows: in the downwind (southern) direction, row Nos. 1, 2, 3, 4, 5, 6, 14, 27, 35, 36, 37, 38, 39, and 40 were sampled; in the upwind (northern) direction, row Nos. 1, 2, 3, 4, 5, 6, 7, 8, 9, 10, 11, 12, 13, 26, 45, 71, 72, 95, 117, and 137 were sampled (Figure 1(a)). Similarly, in the second crop, in the downwind (southern) direction, row Nos. 1, 2, 3, 4, 5, 6, 13, 25, 32, 33, 34, 35, 36, 37, 38, 53, 68, 83, 98, 99, 114, 129, 144, and 159 
were sampled; in the upwind (northern) direction, row Nos. 1, 2, 3, 4, 5, 6, 16, 31, 46, 56, 57, 58, 59, 60 and 61 were sampled (Figure 1(b)). In each sampled row, 3 ears every $12.5 \mathrm{~m}$ were collected during both crop seasons.

Visual inspection of the ears of the pollen recipient was used to calculate the CP rate. Because of the xenia effect, the kernel color of the pollen recipient fertilized by the source pollen was purple. Therefore, CP rate was calculated by counting the number of purple kernels on the white ears of pollen recipients as follows:

$$
\mathrm{CP}(\%)=\frac{\sum_{i=1}^{n} \operatorname{Ear}_{i}}{n \times A V K} \times 100 \%,
$$

where $n$ is the number of ears in each sampling plot, $E a r_{1}$ is the number of purple kernels on the $i^{\text {th }}$ ear of the pollen recipient in each sampling plot, and $A V K$ is the average total kernel number of each ear in the field. To determine $A V K$, one ear from each sampling plot was randomly selected to calculate the total number of kernels individually, and then $A V K$ was calculated for the entire sampling plot.

\subsection{Gene Flow Models}

$\mathrm{CP}$ rates at variable distances from the pollen source were fitted to different empirical models. Three empirical commonly used gene flow models were employed in this study:

$$
\begin{aligned}
& \mathrm{CP}(\%)=b \times e^{a \times d i s} \quad \text { (exponential) } \\
& \mathrm{CP}(\%)=b \times d i s^{a} \quad(\log / \log ) \\
& \mathrm{CP}(\%)=b \times 10^{a \sqrt{d i s}} \quad \text { (log/square) }
\end{aligned}
$$

In all equations, $C P$ is the $\mathrm{CP}$ rate, dis denotes the distance (m) of the sampling plot to the pollen source, and $a$ and $b$ are unknown parameters.

Loos et al. [7] used the Gaussian Plume model [13] to simulate the pollen transport in and from plant canopies, and to mode the distance and CP rate in a field experiment. We adapted the equations from their research [7] [14] to model the relationship between the CP rates of the recipient fields and the distance from the pollen sources as follows:

$$
C P(\%)=\mathrm{b} \times\left[\frac{Q}{2 \sqrt{2 \times(\mathrm{a} \pi)^{3}}} \exp \left(-\frac{x^{2}}{4 \mathrm{a}}-\frac{y^{2}}{4 \mathrm{a}}-\frac{z^{2}}{4 \mathrm{a}}\right)\right]
$$

If a pollen grain from a source plant located at $x_{\mathbf{0}}=\left(x_{0}, y_{0}, z\right)$ pollinates a recipient plant at location $x_{\mathbf{1}}=\left(x_{1}, y_{1}\right.$, $\mathbf{z}$ ), and $\mathbf{z}$ is the average height difference between the source tassel and the recipient ear with silk which is calculated, by randomly choosing 40 source and recipient maize plants. The source strength $\mathrm{Q}$ is the rate of source pollen shed at location x0. According to Marceau et al. [4], the values for Q are 24532.89 grains/s in the first crop season and 54517.54 grains/s in the second crop season, respectively. Under the condition of equal eddy diffusivities, the mean concentration from an instantaneous point source of strength $Q$ may be expressed as the term in the bracket in Equation (1), where $x=x_{1}-x_{0}$ and $y=y_{1}-y_{0}$, and $a$ is an unknown parameter. In addition, the CP rate may be estimated through the mean concentration by using Equation (1), where $b$ is an unknown parameter.

\subsection{Statistical Analysis}

The Statistical Analysis System (SAS) version 9.1.3 (SAS ${ }^{\circledR}$ Institute, Cary, NC, USA) was used as the statistical analysis tool. The mean square error (MSE) and the adjusted coefficient of determination (adj. $\mathrm{R}^{2}$ ) [15] were used to select the best model. Additionally, the scatter plots and the correlation coefficient $(r)$ between predicted and observed values were employed to evaluate the linear relationship. Fitted curves constructed using various models were visually checked against the observed data to achieve the best fit. 


\section{Results}

\subsection{Flowering Synchrony}

Table 1 shows the synchrony between pollen shed of the Black Pearl and the silking of the White Pearl for 2 crop seasons. In the first crop season, the source plot shed 50\% of the pollen by 22 April 2009 and the recipient field reached 50\% silking by 19 April 2009. In the second crop season, the source plot shed $50 \%$ of the pollen by 26 October 2009 and the recipient field reached 50\% silking one day earlier on 25 October 2009. This close synchrony between source plants and recipients represents a worst case for CP from the foreign pollen flow.

\subsection{Weather Patterns}

During the flowering periods, the average wind speed in the second crop season was higher $\left(2.75 \pm 1.09 \mathrm{~m} \cdot \mathrm{s}^{-1}\right)$ than that in the first crop season $\left(1.98 \pm 0.32 \mathrm{~m} \cdot \mathrm{s}^{-1}\right)$. In the first crop season, the average daily wind speed ranged from 1.5 to $2.5 \mathrm{~m} \cdot \mathrm{s}^{-1}$ (Figure 2(a)). The prevailing wind was assumed from the south; however, winds were more commonly from the NW direction and also from the WNW or NNW directions (Figure 3(a)). In the second crop season, the average daily wind speed ranged from 1.35 to $5 \mathrm{~m} \cdot \mathrm{s}^{-1}$ (Figure 2(b)), and winds blew from the NW, NNW, and N directions (Figure 3(b)). This weather pattern was consistent with typical wind

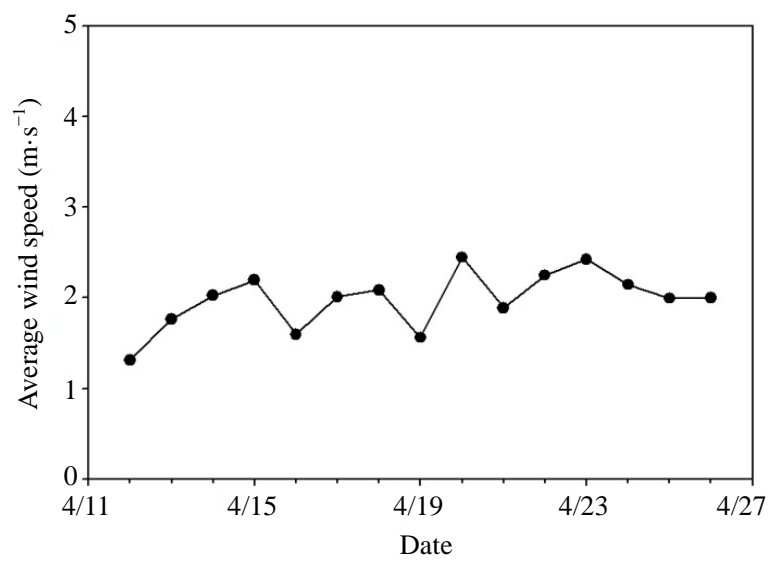

(a)

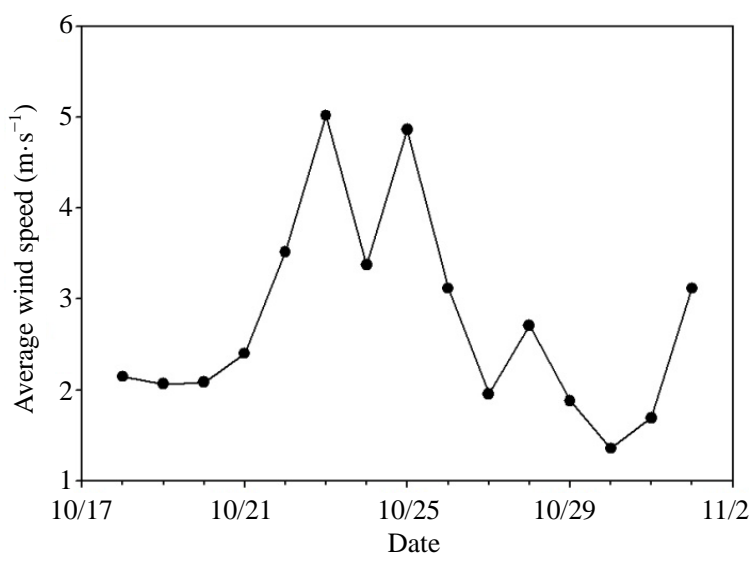

(b)

Figure 2. Mean hourly wind speed $\left(\mathrm{m} \cdot \mathrm{s}^{-1}\right)$ measured hourly between 6:00 a.m. during the flowering periods in 2009. (a) The first crop season; (b) The second crop season.

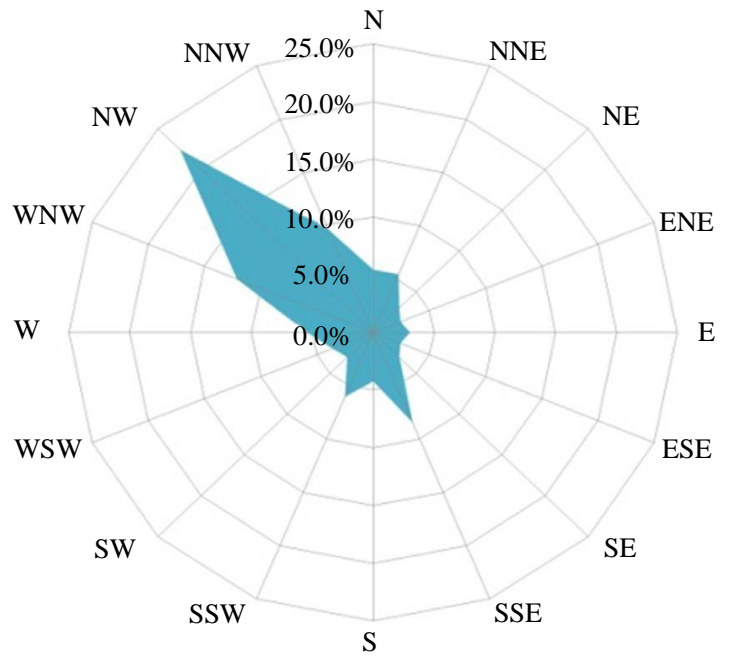

(a)

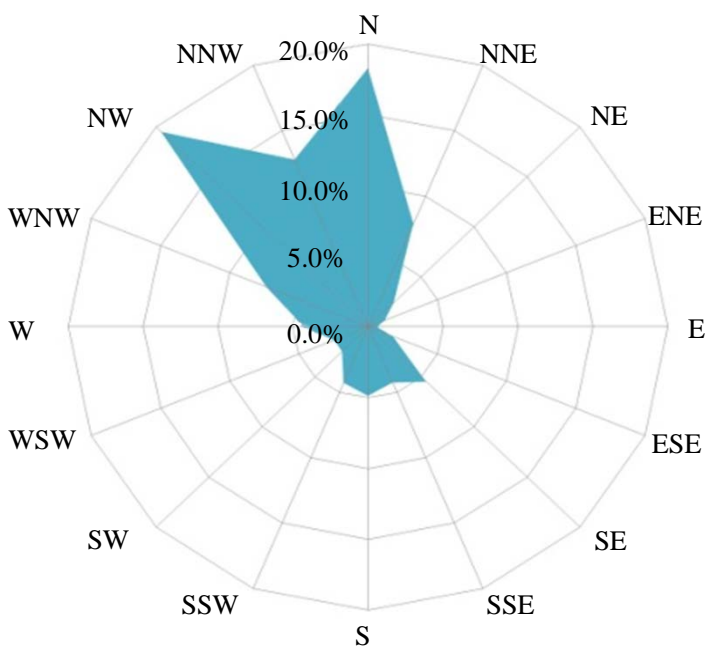

(b)

Figure 3. Wind roses representing frequencies of wind direction measured hourly between 6:00 a.m. during the flowering periods in 2009. (a) The first crop season; (b) The second crop season. 
patterns in the second crop season. The maximum wind speed was $8.68 \mathrm{~m} \cdot \mathrm{s}^{-1}$ in the first crop season and 12.7 $\mathrm{m} \cdot \mathrm{s}^{-1}$ in the second crop season.

According to the weather patterns, in the first crop season the white maize planted in field Nos. 80, 78, and part of 76 were assumed to be in the upwind direction. However, the white maize in the other part of field No. 76 was downwind. In the second crop, the white maize planted in field Nos.76, 78, and part of 80 were assumed to be in the downwind direction and field No. 82 was upwind (Figure 1).

\subsection{Environmental Effects in Actual Filed}

Table 2 shows the ranges and average CP rates in various directions and distances for the first crop season. As expected, the $\mathrm{CP}$ rate was highest in the first row of the recipient field adjacent to the source plot. Although the average CP rate $0.75 \mathrm{~m}$ from the source plot was only $6.07 \%$ downwind compared to $6.33 \%$ in the upwind direction, the majority of the higher average $\mathrm{CP}$ rates were observed downwind rather than upwind. The extent of the $\mathrm{CP}$ rate in the subsequent rows declined rapidly farther from the source plot. In the upwind direction, low levels $(0 \%-0.24 \%)$ of $\mathrm{CP}$ rates were recorded at $15 \mathrm{~m}$, and decreased to $0 \%$ thereafter. However, in the downwind direction, a $0 \%$ to $0.24 \% \mathrm{CP}$ rate was recorded at $28.5 \mathrm{~m}$. The average $\mathrm{CP}$ rate reached $0 \%$ at $29.25 \mathrm{~m}$, but the average was $0.08 \%(0 \%-0.49 \%)$ at $30 \mathrm{~m}$. The average CP rate in the downwind direction was higher in the second crop season (19.75\%) than in the first crop season (6.07\%), and the CP rate declined when distances increased from the source plot (Table 2, Table 3). In the upwind direction, the average CP rate at $6.05 \mathrm{~m}$ from the source plot was $0.38 \%$ and decreased in the subsequent rows. The average CP rate was never $0 \%$ within $50.3 \mathrm{~m}$ and $131.3 \mathrm{~m}$ where samples were collected in upwind and downwind directions, respectively (Table 3).

In the first crop season, the average CP rates were approximately 5.32\% - 6.40\% from 0 to $3 \mathrm{~m}$ (Table 4). The average $\mathrm{CP}$ rates were greater in the east and south than in the west and north. Similarly, a greater distance from the source plot indicated a lower CP rate. At a distance of $10-20 \mathrm{~m}$, the average CP rates were higher in the south $(0.34 \%)$ than in the north $(0.06 \%)$ and were higher in the east $(0.07 \%)$ than in the west $(0.02 \%)$. The results are consistent with the wind direction of NW. In the second crop season, the average CP rates were $11.69 \%$ in the east and $15.70 \%$ in the south compared to $0.34 \%$ in the north and $3.19 \%$ in the west at 0 - $3 \mathrm{~m}$ (Table 5). Similar patterns were observed at distances of $20-25 \mathrm{~m}$. The average CP rate was $0 \%$ beyond $50 \mathrm{~m}$ in the first crop season but was never $0 \%$ within $131.3 \mathrm{~m}$ in the second crop season (Table 4, Table 5).

\subsection{Performance of the Gene Flow Models}

Three empirical models and one semi-empirical model were used to predict the CP rates at various distances,

Table 2. Mean and range of cross-pollination rate (\%) in the first crop season.

\begin{tabular}{cccccc}
\hline & \multicolumn{2}{c}{ Upwind } & \multicolumn{2}{c}{ Downwind } \\
\hline Distance (m) & Range (\%) & Mean \pm sd (\%) & Distance (m) & Range (\%) & Mean \pm sd (\%) \\
\hline 0.75 & $0-24.94$ & $6.33 \pm 9.02$ & 0.75 & $0-25.92$ & $6.07 \pm 8.25$ \\
1.5 & $0-2.93$ & $0.73 \pm 1.25$ & 1.5 & $0-4.16$ & $1.52 \pm 2.00$ \\
2.25 & $0-1.96$ & $0.54 \pm 0.82$ & 2.25 & $0-0.98$ & $0.31 \pm 0.46$ \\
3 & $0-0.73$ & $0.29 \pm 0.32$ & 3 & $0-2.44$ & $0.67 \pm 1.19$ \\
3.75 & $0-0.24$ & $0.05 \pm 0.11$ & 3.75 & $0-8.07$ & $3.33 \pm 4.33$ \\
4.5 & $0-3.91$ & $0.17 \pm 0.70$ & 4.5 & $0-5.87$ & $2.10 \pm 2.57$ \\
7.5 & 0 & 0.00 & 10.5 & $0-1.96$ & $0.18 \pm 0.39$ \\
15 & $0-0.24$ & $0.05 \pm 0.11$ & 20.25 & $0-1.96$ & $0.10 \pm 0.33$ \\
24 & 0 & 0.00 & 28.5 & $0-0.24$ & $0.05 \pm 0.11$ \\
68 & 0 & 0.00 & 29.25 & 0 & 0.00 \\
98 & 0 & 0.00 & 30 & $0-0.49$ & $0.08 \pm 0.20$ \\
\hline
\end{tabular}


Table 3. Mean and range of cross-pollination rate (\%) in the second crop season.

\begin{tabular}{cccccc}
\hline & \multicolumn{2}{c}{ Upwind } & \multicolumn{2}{c}{ Downwind } \\
\hline Distance (m) & Range (\%) & Mean \pm sd (\%) & Distance (m) & Range (\%) & Mean \pm sd (\%) \\
\hline 6.05 & $0.08-0.71$ & $0.38 \pm 0.24$ & 0.75 & $5.66-38.01$ & $19.75 \pm 13.49$ \\
7.55 & $0.04-0.40$ & $0.13 \pm 0.15$ & 2.25 & $6.33-16.39$ & $8.95 \pm 6.54$ \\
9.05 & $0.04-0.33$ & $0.10 \pm 0.14$ & 3.75 & $3.60-8.95$ & $6.64 \pm 2.75$ \\
10.55 & $0-0.05$ & $0.03 \pm 0.02$ & 5.25 & $0-9.46$ & $1.36 \pm 2.69$ \\
12.05 & $0-0.12$ & $0.05 \pm 0.05$ & 9.75 & $0.24-2.97$ & $1.19 \pm 0.86$ \\
13.55 & $0-0.04$ & $0.02 \pm 0.02$ & 18.75 & $0.11-1.43$ & $0.64 \pm 0.49$ \\
16.55 & $0-0.08$ & $0.01 \pm 0.03$ & 27.75 & $0-1.62$ & $0.38 \pm 0.46$ \\
27.8 & $0-0.04$ & $0.01 \pm 0.02$ & 39.45 & $0-0.40$ & $0.18 \pm 0.16$ \\
39.05 & $0-0.08$ & $0.01 \pm 0.02$ & 58.95 & $0-0.48$ & $0.04 \pm 0.08$ \\
50.3 & $0-0.04$ & $0.01 \pm 0.02$ & 70.2 & $0-0.20$ & $0.04 \pm 0.05$ \\
& & & 97.55 & $0-0.20$ & $0.03 \pm 0.06$ \\
& & & 120.05 & $0-0.08$ & $0.01 \pm 0.02$ \\
\end{tabular}

Table 4. Rate of cross-fertilization (\%) at each direction (N, S, W, E) in the first crop season.

\begin{tabular}{|c|c|c|c|c|c|}
\hline \multirow[t]{2}{*}{ Distance (m) } & \multicolumn{4}{|c|}{$1^{\text {st }}$ crop season } & \multirow[t]{2}{*}{ Avg } \\
\hline & $\mathrm{N}$ & $\mathrm{S}$ & W & $\mathrm{E}$ & \\
\hline $0-3$ & $5.32 \pm 8.41$ & $6.40 \pm 8.00$ & $5.40 \pm 8.91$ & $5.55 \pm 7.19$ & 5.64 \\
\hline $3-6$ & $0.15 \pm 0.22$ & $2.61 \pm 3.34$ & $0.09 \pm 0.14$ & $0.82 \pm 1.07$ & 0.61 \\
\hline $10-20$ & $0.06 \pm 0.15$ & $0.34 \pm 0.54$ & $0.02 \pm 0.17$ & $0.07 \pm 0.34$ & 0.06 \\
\hline $20-30$ & 0.00 & $0.03 \pm 0.08$ & n.d. & n.d. & 0.04 \\
\hline $50-60$ & 0.00 & n.d. ${ }^{a}$ & n.d. & n.d. & 0.00 \\
\hline $90-100$ & 0.00 & n.d. & n.d. & n.d. & 0.00 \\
\hline
\end{tabular}

${ }^{\text {a }}$ no data collected.

Table 5. Rate of cross-fertilization (\%) at each direction (N, S, W, E) in the second crop season.

\begin{tabular}{|c|c|c|c|c|c|}
\hline \multirow[t]{2}{*}{ Distance (m) } & \multicolumn{4}{|c|}{$2^{\text {nd }}$ crop season } & \multirow[t]{2}{*}{ Avg } \\
\hline & $\mathrm{N}$ & $\mathrm{S}$ & W & $\mathrm{E}$ & \\
\hline $0-3$ & $0.34 \pm 0.24$ & $15.70 \pm 12.14$ & $3.19 \pm 4.65$ & $11.69 \pm 8.95$ & 8.00 \\
\hline $3-6$ & $0.06 \pm 0.11$ & $7.00 \pm 4.25$ & $0.15 \pm 0.22$ & $1.63 \pm 0.86$ & 2.42 \\
\hline $6-9$ & $0.03 \pm 0.04$ & $2.80 \pm 0.74$ & $0.13 \pm 0.13$ & $0.52 \pm 0.39$ & 0.89 \\
\hline $20-25$ & $0.01 \pm 0.02$ & $0.66 \pm 0.40$ & 0 & $0.13 \pm 0.12$ & 0.24 \\
\hline $35-40$ & $0.01 \pm 0.02$ & $0.57 \pm 0.46$ & n.d. & n.d. & 0.06 \\
\hline $70-80$ & n.d. ${ }^{a}$ & $0.04 \pm 0.05$ & n.d. & n.d. & 0.03 \\
\hline $120-131.3$ & n.d. & $0.01 \pm 0.02$ & n.d. & n.d. & 0.01 \\
\hline
\end{tabular}

ano data collected. 
and the suitability of these models were compared (Table 6). Considering the upwind direction, data for the first crop season fitted by the Gaussian Plume model performed best with the largest $\mathrm{R}^{2}$ value and the smallest MSE $\left(\operatorname{adj} . \mathrm{R}^{2}=0.845\right.$, MSE $\left.=0.7\right)$. However, the log/log model had the best fitting ability in the second crop season $\left(\right.$ adj. $R^{2}=0.693$, MSE $\left.=0.004\right)$. The relationship among the predicted verse measured $\mathrm{CP}$ rates showed the same tendency (Figure 4, Figure 5). The Gaussian Plume model had the largest $r$ value of 0.92 in the first crop

Table 6. Mean squared error (MSE), adjusted coefficient of determination (adj $\mathrm{R}^{2}$ ) of the four models in both crop seasons.

\begin{tabular}{|c|c|c|c|c|c|c|c|c|}
\hline \multirow[b]{3}{*}{ Model } & \multicolumn{4}{|c|}{$1^{\text {st }}$ crop season } & \multicolumn{4}{|c|}{$2^{\text {nd }}$ crop season } \\
\hline & \multicolumn{2}{|c|}{ Up wind } & \multicolumn{2}{|c|}{ Down wind } & \multicolumn{2}{|c|}{ Up wind } & \multicolumn{2}{|c|}{ Down wind } \\
\hline & MSE & Adj $\mathrm{R}^{2}$ & MSE & Adj $R^{2}$ & MSE & Adj $\mathrm{R}^{2}$ & MSE & Adj $\mathrm{R}^{2}$ \\
\hline exponential & 0.98 & 0.689 & 4.75 & 0.471 & 0.004 & 0.687 & 3.35 & 0.559 \\
\hline $\log / \log$ & 0.99 & 0.685 & 4.50 & 0.499 & 0.004 & 0.693 & 3.60 & 0.526 \\
\hline log/square & 0.99 & 0.687 & 4.62 & 0.485 & 0.004 & 0.690 & 3.40 & 0.552 \\
\hline Gaussian & 0.70 & 0.845 & 5.37 & 0.401 & 0.004 & 0.681 & 3.31 & 0.565 \\
\hline
\end{tabular}

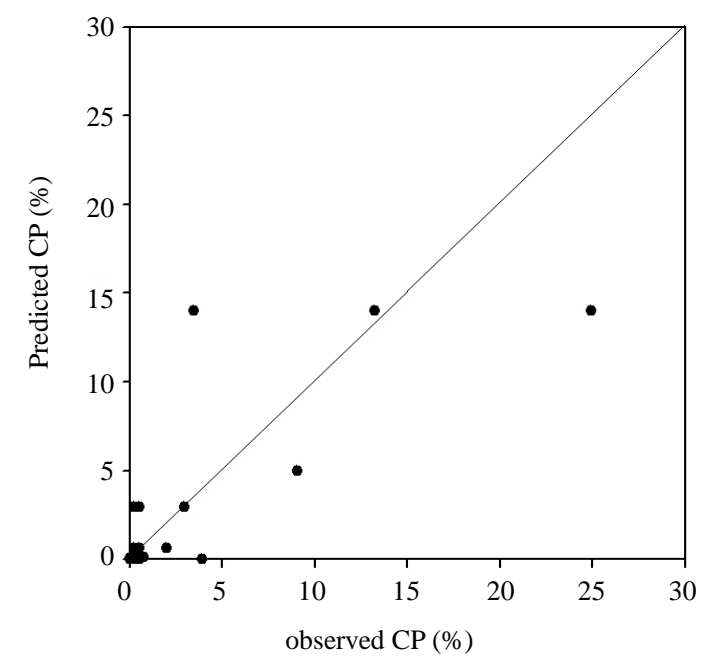

(a)

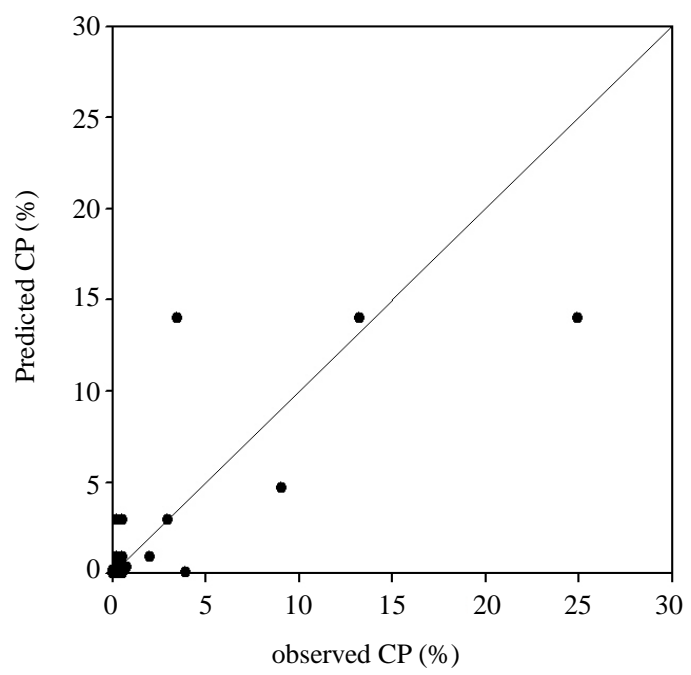

(c)

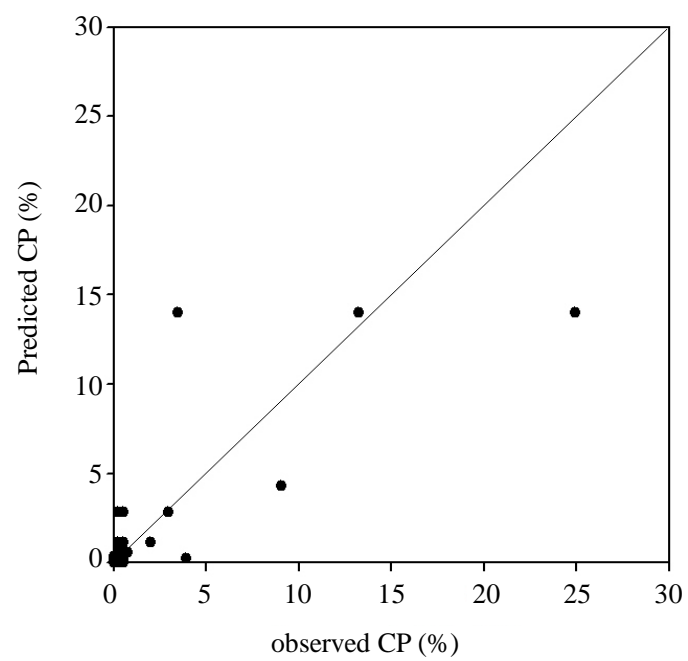

(b)

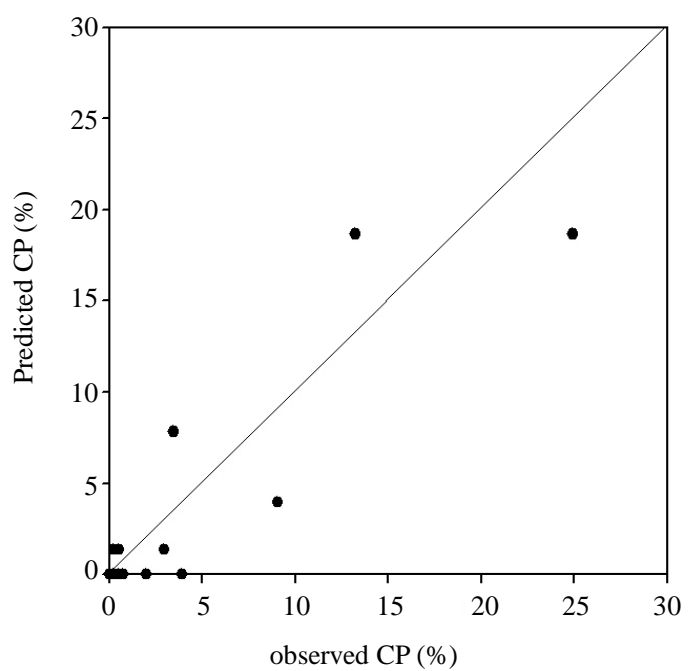

(d)

Figure 4. Scatter plots of observed and model-estimated cross-pollination rate in upwind direction in the first crop season (n = 290). (a) Exponential ( $\mathrm{r}=0.83)$; (b) Log/log ( $\mathrm{r}=0.83$ ); (c) Log/square ( $\mathrm{r}=0.83$ ); (d) Gaussian plume model $(\mathrm{r}=0.92)$. 


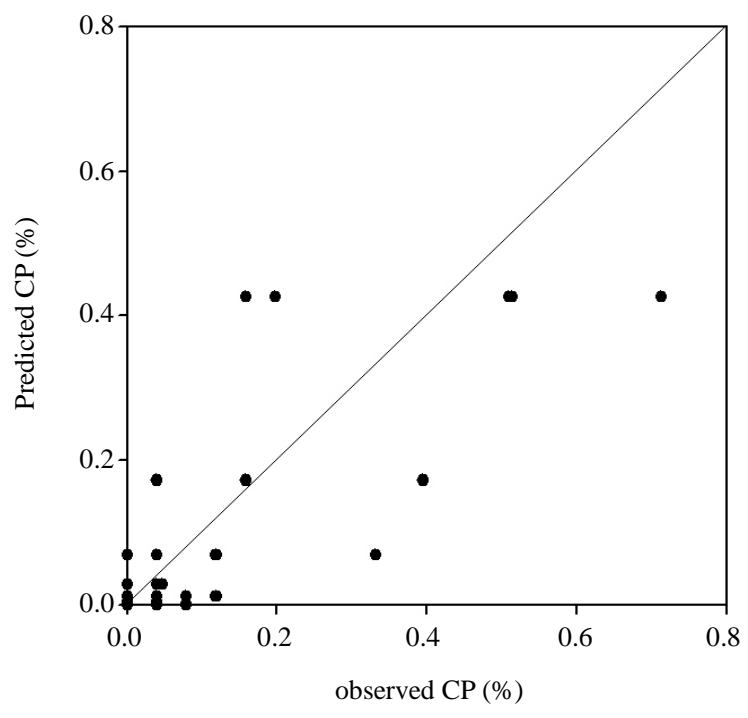

(a)

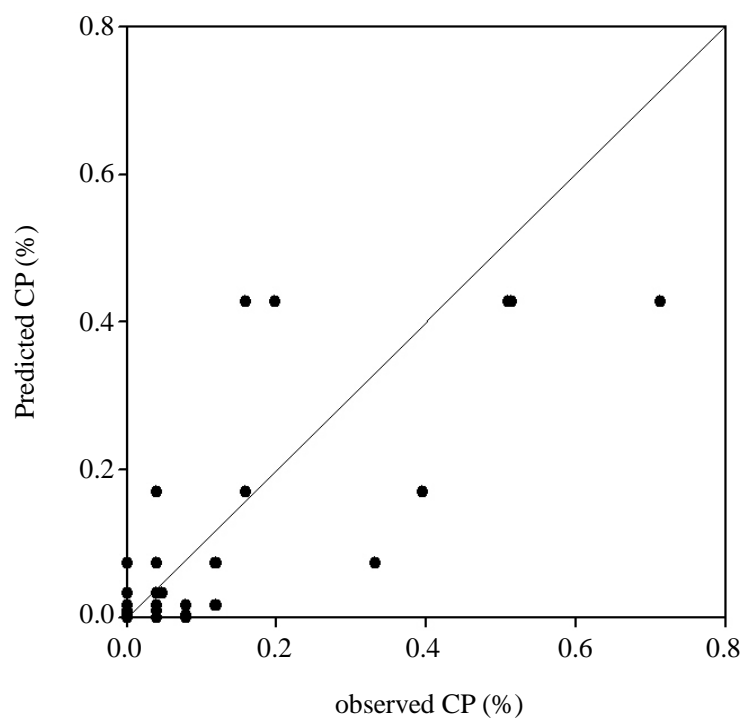

(c)

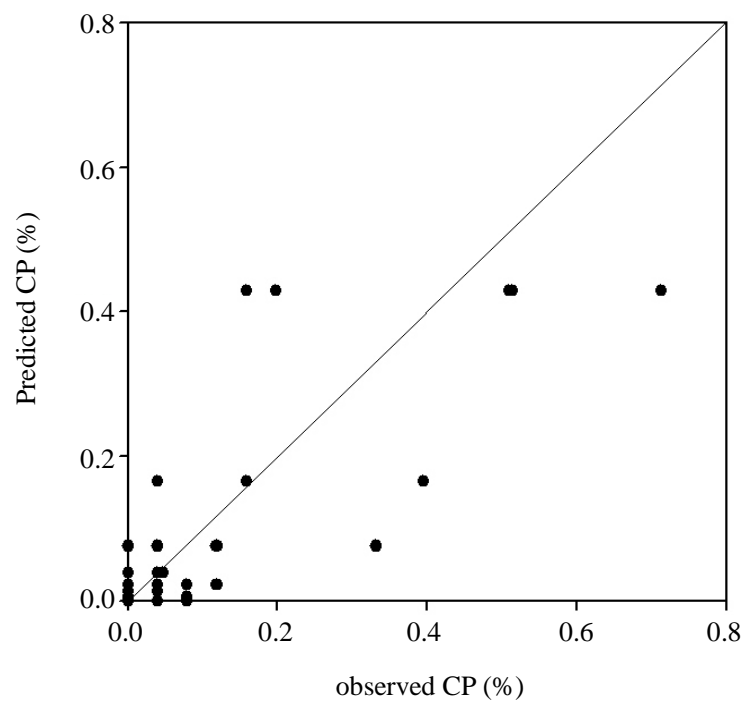

(b)

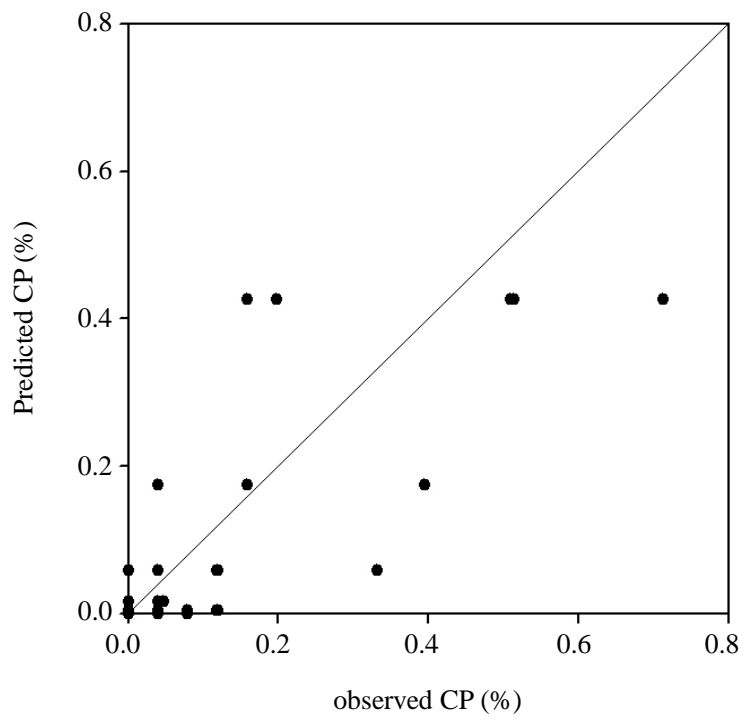

(d)

Figure 5. Scatter plots of observed and model-estimated cross-pollination rate in upwind direction in the second crop season ( $n=115)$. (a) Exponential ( $\mathrm{r}=0.83)$; (b) $\log / \log (\mathrm{r}=0.84)$; (c) Log/square ( $\mathrm{r}=0.84)$; (d) Gaussian plume model $(\mathrm{r}=0.83)$.

season and had the second largest $r$ value (0.83) in the second crop season. One sample collected at $0.75 \mathrm{~m} \mathrm{had} \mathrm{a}$ higher actual CP rate of 24.94\%, but the CP rates were underestimated by all models (13\% - 18\%) (Figure 4 ). In the second crop season, all actual and predicted CP rates were below 1\%. With the exception of the Gaussian Plume model in the first crop season, the fitting ability of all of the models used was nearly the same in both crop seasons. When inspecting the downwind direction, the log/log model had the best fitting ability in the first crop season (adj. $\mathrm{R}^{2}=0.499$, MSE $=4.5$ ), and the Gaussian Plume model performed best in the second crop season (adj. $\mathrm{R}^{2}=0.565$, MSE $=3.31$ ), as shown in Table 6 . One sample collected at $0.75 \mathrm{~m}$ in the first crop season had a higher actual CP rate of 26.9\%; however, the CP values predicted by all models were between $9.8 \%$ and 10.1\% (Figure 6). In the second crop season, the CP rates of 4 samples collected at short distances from the source field (1 - $3 \mathrm{~m}$ ) were underestimated (Figure 7). The actual values were 38\%, 29\%, 27\%, and 16\%, but the predicted values were $13.6 \%, 13.6 \%, 16.7 \%$, and $7.5 \%$, respectively, indicating that the samples with higher CP rates could be underestimated at short distances. In addition, all models achieved nearly identical fitting abilities in both seasons. 


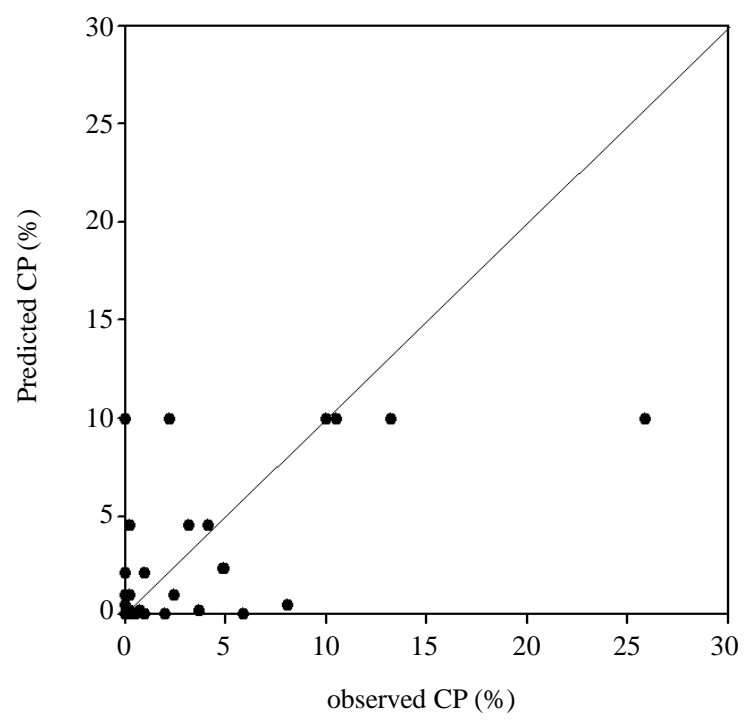

(a)

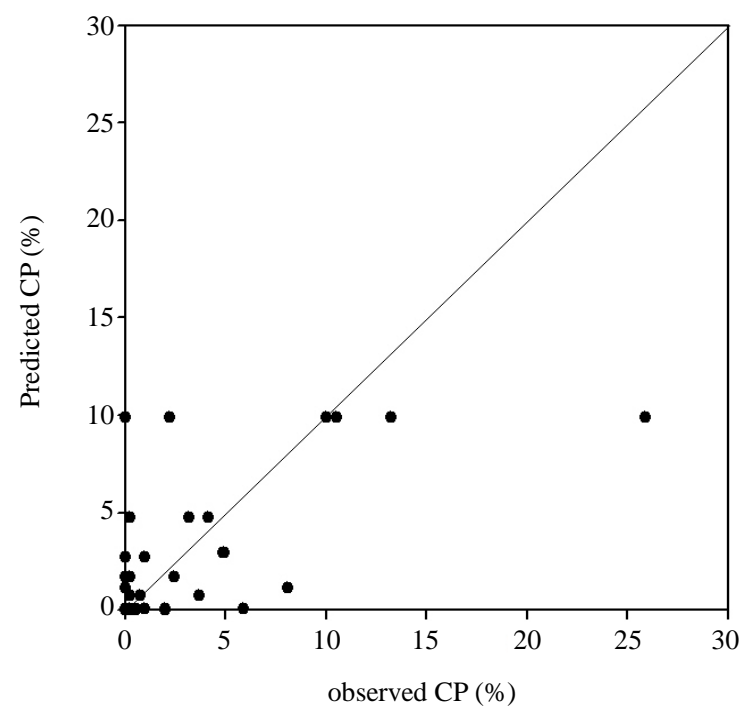

(c)

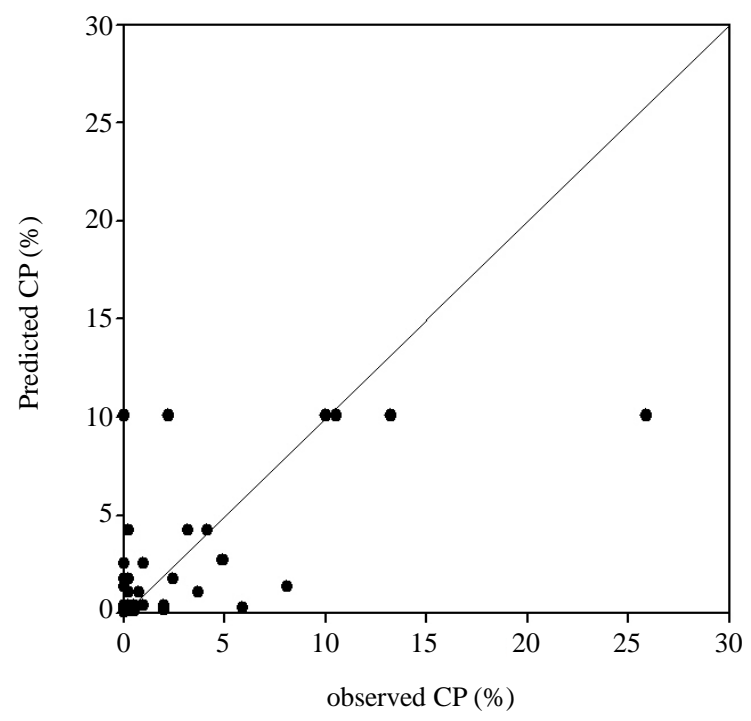

(b)

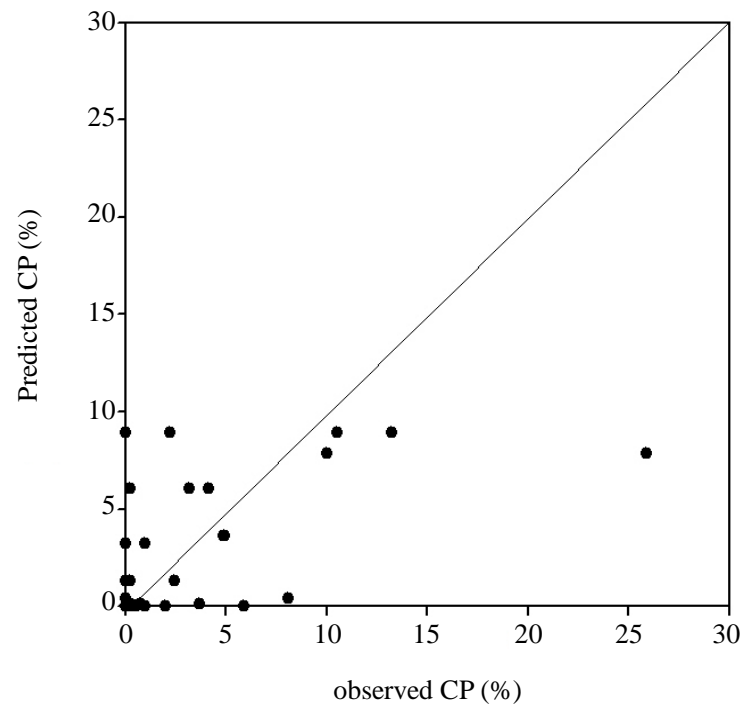

(d)

Figure 6. Scatter plots of observed and model-estimated cross-pollination rate in downwind direction in the first crop season ( $n=136)$. (a) Exponential ( $r=0.69)$; (b) $\log / \log (r=0.71)$; (c) Log/square ( $r=0.70)$; (d) Gaussian plume model $(r=0.64)$.

Figure 8, Figure 9 show the predicted CP rates using the various models, based on the distance from the source plot under upwind and downwind directions, in the first and second crop seasons, respectively. Regardless of the directions, the CP rates predicted by all of the models declined with increasing distances from the source plot. When inspecting the upwind direction, the CP rates predicted by the Gaussian Plume model declined more rapidly compared with the other models in both seasons (Figure 8(a), Figure 9(a)). The distances predicted to reach the CP rate of $0 \%$ were $2.5 \mathrm{~m}$ in the first crop season and $15 \mathrm{~m}$ in the second crop season when using the Gaussian Plume model. The trends of the regression curves represented by different models were similar except within 3 rows $(2.25 \mathrm{~m})$ from the source plot in the first crop, and ranging between 8 and $15 \mathrm{~m}$ in the second crop season. In the downwind direction, the CP rate predicted by the Gaussian Plume model also declined more rapidly and was $0 \%$ at $10 \mathrm{~m}$ in both seasons (Figure 8(b), Figure 9(b)). The tendencies of the regression curves predicted by the three empirical models in the downwind direction were more diverse than those predicted for the upwind direction, especially nearer the source plot, thus showing the influence of wind direction during flowering. 


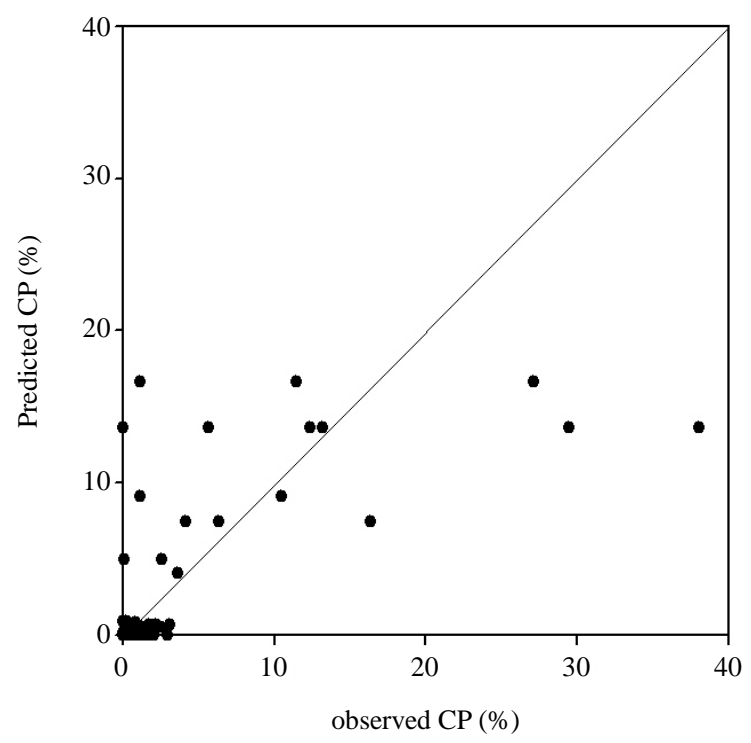

(a)

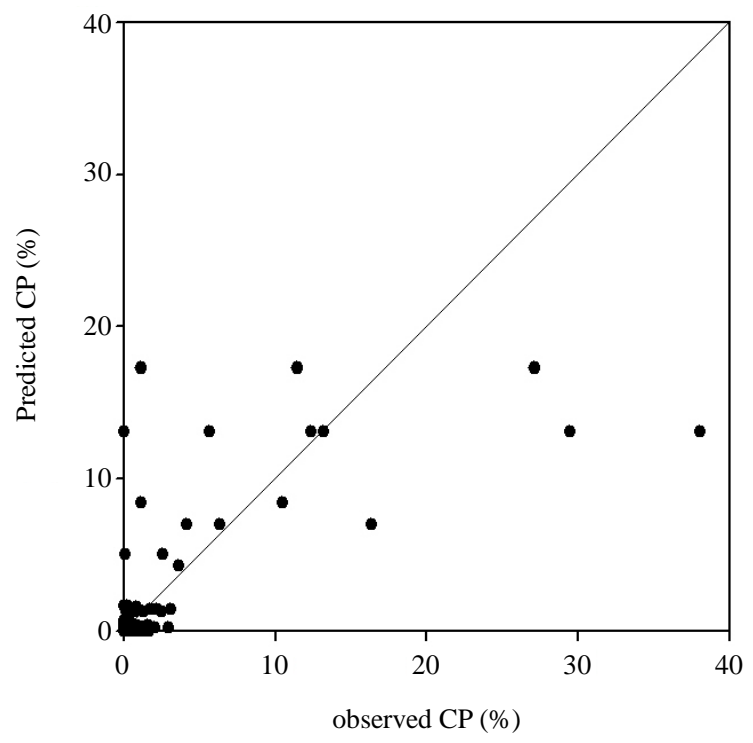

(c)

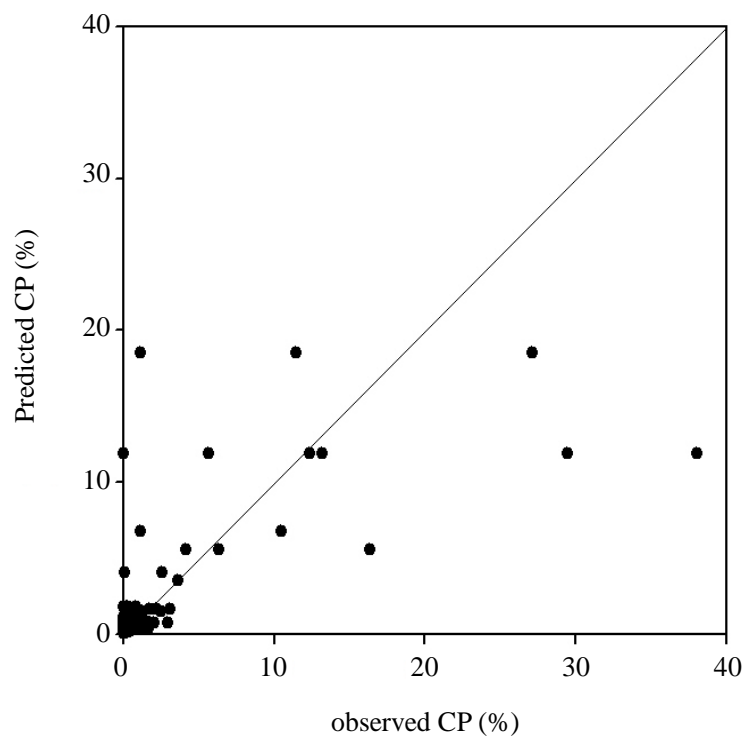

(b)

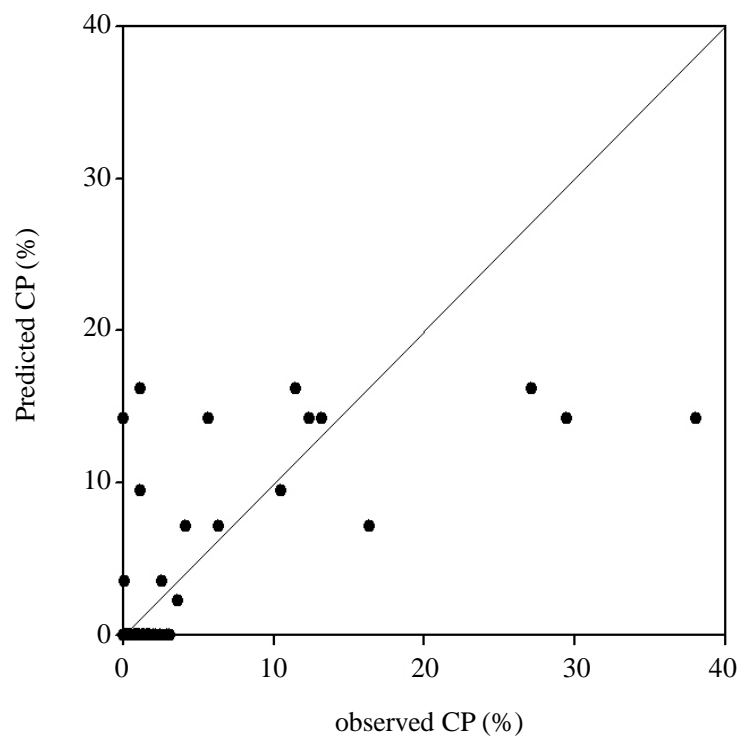

(d)

Figure 7. Scatter plots of observed and model-estimated cross-pollination rate in downwind direction in the second crop season ( $\mathrm{n}=522)$. (a) Exponential $(\mathrm{r}=0.75)$; (b) Log/log ( $\mathrm{r}=0.73)$; (c) Log/square ( $\mathrm{r}=0.74)$; (d) Gaussian plume model ( $\mathrm{r}=$ $0.75)$.

\section{Discussion}

In the first report of this study, it was observed that the $\mathrm{CP}$ rate declined rapidly with increasing distance from the source field. The CP rates at short distances were more variable. These results are in agreement with those from other studies [2] [6]-[11]. The CP rates of the recipients were well fitted by the four models in this study. However, the samples with higher $\mathrm{CP}$ rates adjacent to the pollen source were underestimated when using these models. In contrast, Loos et al. [7] observed tendencies in overestimation using the Gaussian Plume model and LNF theory on their data in farther distances from the source field.

The area ratio of pollen sources and recipients was approximately 1:32 in the first crop season and 1:17.3 in the second crop season. Higher CP rates were expected in the second crop season than in the first crop season. Large recipient fields have their own large amounts of pollen flows [11]. This recipient pollen cloud becomes a 


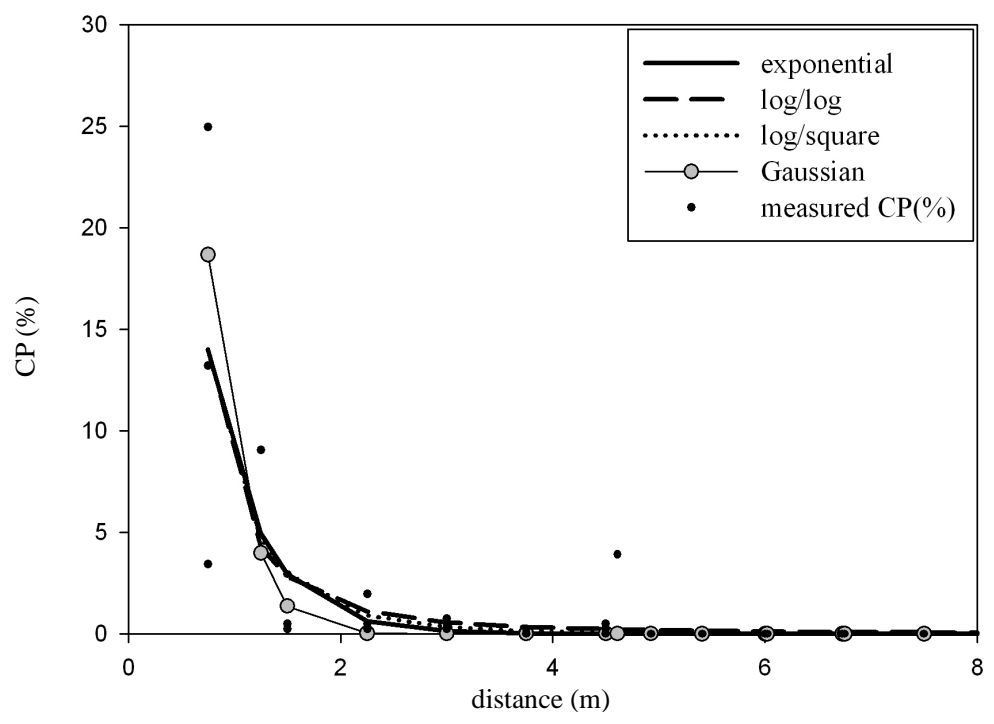

(a)

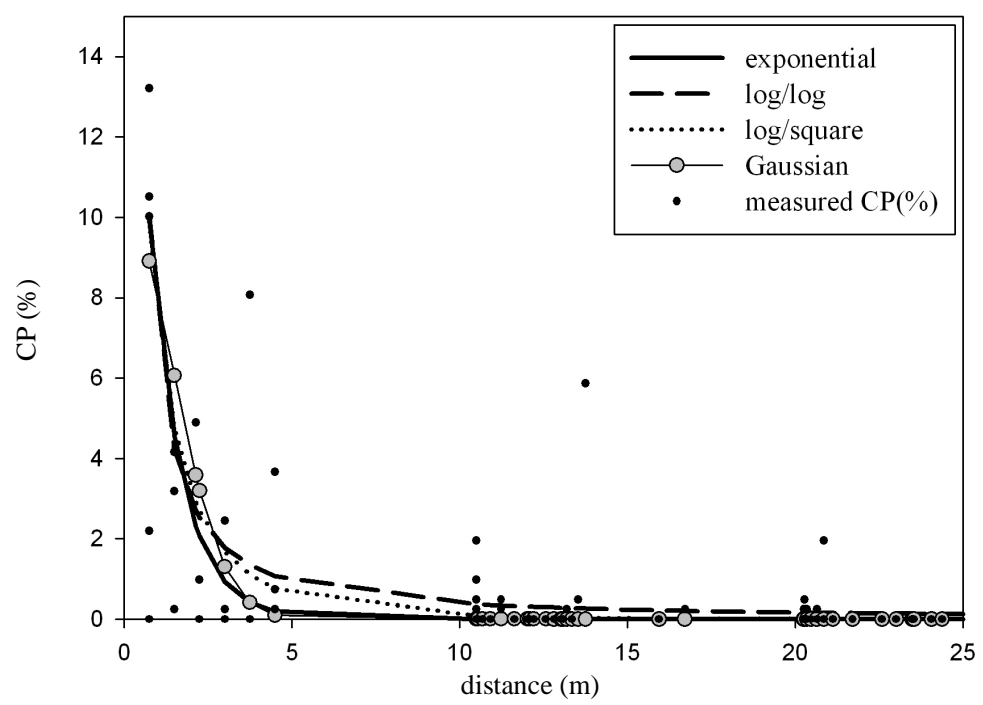

(b)

Figure 8. Scatter plots of observed (dot) and model-estimated (line) cross-pollination (\%) in the first crop season. (a) Upwind direction; (b) Downwind direction.

natural barrier and competitor for the source pollen. Apart from the relative sizes of the source and recipient fields, the wind direction and average wind speed in the second crop season provided favorable conditions for achieving higher CP rates. These results are consistent with the work of Ma et al. [2] who reported that the CP rates were $<1 \%$ at a distance of $28 \mathrm{~m}$ downwind, but at a distance of $10 \mathrm{~m}$ upwind in all sites and years tested.

Because the pollen grains of maize are heavy $(0.25 \mu \mathrm{g})$ and large (average diameter of $90 \mu \mathrm{m})$ compared to that of other wind-pollinated crops, maize pollen settles rapidly and in proximity of the source [16] [17]. Small amounts of pollen are detected at 800 and $1000 \mathrm{~m}$ from the source, given favorable wind directions and speeds [17]. Our data showed that the rate of CP was $<0.05 \%$ beyond $15 \mathrm{~m}$ upwind and $84.8 \mathrm{~m}$ downwind in all crop seasons. The CP rate was below $5 \%$ at a distance of $10 \mathrm{~m}$ in the downwind direction. A sample with $0.24 \% \mathrm{CP}$ was recorded at $107.3 \mathrm{~m}$ downwind; however, the $\mathrm{CP}$ rate was $0 \%$ at $68 \mathrm{~m}$ upwind. Our results support the recommendations made by Devos et al. [5] that surrounding pollen sources with ranges of isolation distances between 10 and $50 \mathrm{~m}$ is effective to maintain a CP rate below the threshold of $0.9 \%$ without any additional temporal isolation. 


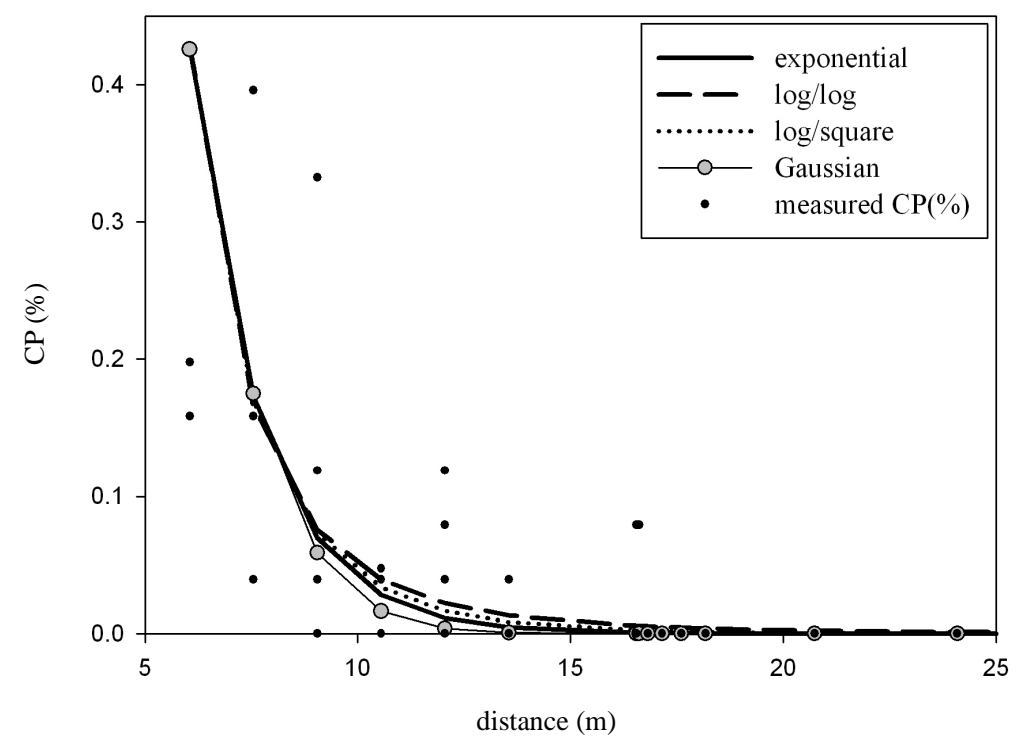

(a)

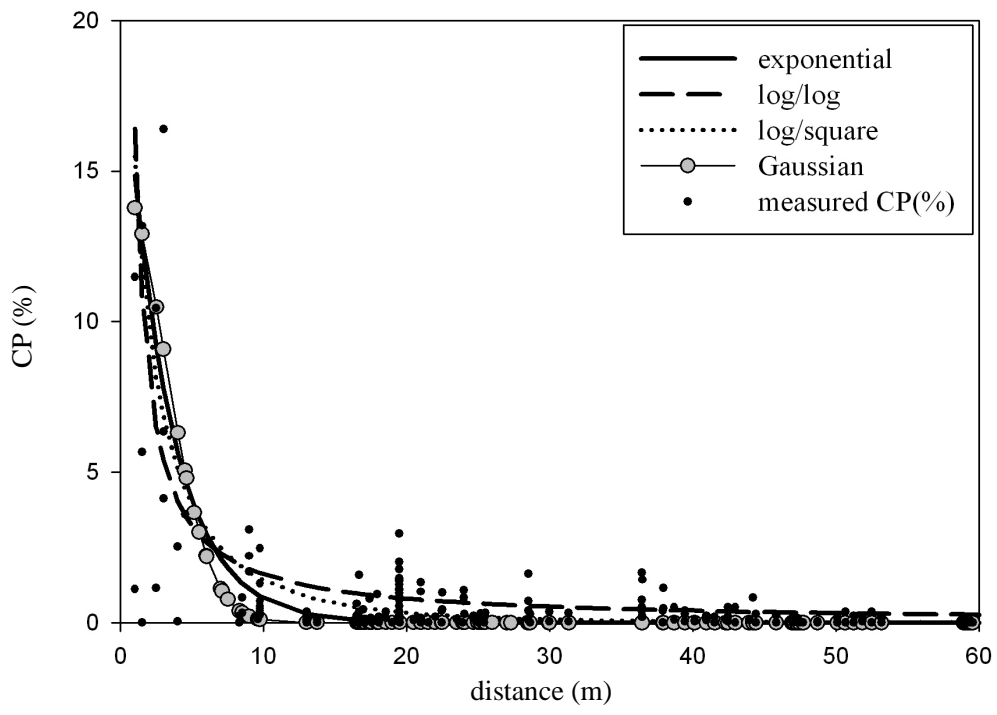

(b)

Figure 9. Scatter plots of observed (dot) and model-estimated (line) cross-pollination (\%) in the second crop season. (a) Upwind direction; (b) Downwind direction.

None of the models used in this study were excellent in simulating the field data because the $\mathrm{R}^{2}$ values were not large, which indicated that biological (e.g., the height of male and female flowers) and aerodynamic factors (e.g., wind speed, wind direction, pollen settling velocity, and air turbulence) must be considered when modeling gene flow. The CP rates of the recipient at various distances from the source are well fitted by the Gaussian Plume model compared with other empirical models. Therefore, future works should introduce important biological, agricultural, and climatic parameters into proposed models to test the influence of these parameters on maize gene flow, and to create a more useful maize gene flow model.

To ensure a close synchrony between the recipients and pollen donors, the pollen donor was divided into 2 batches and planted on different days in the first crop season. In the second crop season, both pollen donors and recipients were planted on the same day. However, higher levels of CP rates were observed in the second crop season. The effects of asynchrony of flowering time between source plants and recipients on CP rates should be studied further. 


\section{Conclusion}

This study was the first to construct the field experiment in Taiwan to measure the CP rate for simulating the GM maize. By using phenotypic marker and determining the isolation distance between the 2 maize varieties, this study detected the effects on the CP rate of maize at a field-scale level. Accordingly, the results showed that the CP rate was affected by distance, area ratio of source and recipient, wind direction, and synchrony of flowering time. It is effective to maintain a CP rate below $0.9 \%$ without any additional temporal isolation by surrounding pollen sources with ranges of isolation distances between 10 and $50 \mathrm{~m}$. Moreover, the Gaussian Plume model fitted better than the other empirical models. However, the small scale of agricultural landscapes is one common situation in Taiwan which has a subtropical insular climate. Therefore, meteorological elements and biotic factors must be considered for investigating the gene flow in Taiwan to further improve the performance of model fitting and prediction.

\section{References}

[1] James, C. (2013) Global Status of Commercialized Biotech/GM Crops: 2012. ISAAA Brief, ISAAA, Ithaca.

[2] Ma, B.L., Subedi, K.D. and Reid, L.M. (2004) Extent of Cross-Fertilization in Maize by Pollen from Neighboring Transgenic Hybrids. Crop Science, 44, 1273-1282. http://dx.doi.org/10.2135/cropsci2004.1273

[3] Palaudelmás, M., Melé, E., Peñas, G., Pla, M., Nadal, A., Serra, J., Salvia, J. and Messeguer, J. (2008) Sowing and Flowering Delays Can Be an Efficient Strategy to Improve Coexistence of Genetically Modified and Conventional Maize. Crop Science, 48, 2404-2413.

[4] Marceau, A., Loubet, B., Andrieu, B., Dur, B., Foueillassar, X. and Huber, L. (2011) Modeling Diurnal and Seasonal Patterns of Maize Pollen Emission in Relation to Meteorological Factors. Agricultural and Forest Meteorology, 151, 11-21. http://dx.doi.org/10.1016/j.agrformet.2010.08.012

[5] Devos, Y., Demont, M., Dillen, K., Reheul, D., Kaiser, M. and Sanvido, O. (2009) Coexistence of Genetically Modified (GM) and Non-GM Crops in the European Union. A Review. Agronomy for Sustainable Development, 29, 11-30. http://dx.doi.org/10.1051/agro:2008051

[6] Luna, S.V., Figueroa, J.M., Baltazar, B.M., Gomez, R.L., Townsend, R. and Schoper, J.B. (2001) Maize Pollen Longevity and Distance Isolation Requirements for Effective Pollen Control. Crop Science, 41, 1551-1557. http://dx.doi.org/10.2135/cropsci2001.4151551x

[7] Loos, C., Seppelt, R., Meier-Bethke, S., Schiemann, J. and Richter, O. (2003) Spatially Explicit Modeling of Transgenic Maize Pollen Dispersal and Cross-Pollination. Journal of Theoretical Biology, 225, 241-255. http://dx.doi.org/10.1016/S0022-5193(03)00243-1

[8] Gustafson, D.I., Horak, M.J., Rempel, C.B., Metz, S.G., Gigax, D.R. and Hucl, P. (2005) An Empirical Model for Pollen-Mediated Gene Flow in Wheat. Crop Science, 45, 1286-1294. http://dx.doi.org/10.2135/cropsci2004.0137

[9] Halsey, M.E., Remund, K.M., Davis, C.A., Qualls, M., Eppard, P.J. and Berberich, S.A. (2005) Isolation of Maize from Pollen-Mediated Gene Flow by Time and Distance. Crop Science, 45, 2172-2185. http://dx.doi.org/10.2135/cropsci2003.0664

[10] Messeguer, J., Penas, G., Ballester, J., Bas, M., Serra, J., Salvia, J., Palaudelmas, M. and Mele, E. (2006) Pollen-Mediated Gene Flow in Maize in Real Situations of Coexistence. Plant Biotechnology Journal, 4, 633-645. http://dx.doi.org/10.1111/j.1467-7652.2006.00207.x

[11] Della Porta, G., Ederle, D., Bucchini, L., Prandi, M., Verderio, A. and Pozzi, C. (2008) Maize Pollen Mediated Gene Flow in the Po Valley (Italy): Source-Recipient Distance and Effect of Flowering Time. European Journal of Agronomy, 28, 255-265. http://dx.doi.org/10.1016/j.eja.2007.07.009

[12] Frederick, C. (2011) Taiwan Biotechnology Annual Report. USDA Foreign Agricultural Service.

[13] Pasquill, F. (1974) Atmospheric Diffusion, 2nd Edition, Wiley, New York.

[14] Yao, K., Hu, N., Cheng, W., Li, R., Yuan, Q., Wang, F., Qian, Q. and Jia, S. (2008) Establishment of a Rice Transgene Flow Model for Predicting Maximum Distances of Gene Flow in Southern China. New Phytologist, 180, 217-228. http://dx.doi.org/10.1111/j.1469-8137.2008.02555.x

[15] Neter, J., Kutner, M.H., Nachtsheim, C.J. and Wasserman, W. (1996) Applied Linear Statistical Models. 4th Edition, McGraw-Hill Professional Publishing, New York.

[16] Aylor, D.E., Schultes, N.P. and Schields, E.J. (2003) An Aerobiological Framework for Assessing Cross-Pollination in Maize. Agricultural and Forest Meteorology, 119, 111-129. http://dx.doi.org/10.1016/S0168-1923(03)00159-X

[17] Jarosz, N., Loubet, B., Durand, B., Foueillassar, X. and Huber, L. (2005) Variations in Maize Pollen Emission and Deposition in Relation to Microclimate. Environmental Science \& Technology, 39, 4377-4384. http://dx.doi.org/10.1021/es0494252 